Electrical \& Computer Engineering: An International Journal (ECIJ) Vol.6, No.1/2, June 2017

\title{
MODELING AND SiMULATION OF SOLAR Photovoltaic Application Based Multilevel INVERTER WITH REDUCED COUNT TOPOLOGY FOR STAND-ALONE SYSTEM
}

\author{
Amarnath, R.K. Nema, Deepak Verma \\ Department of Electrical Engineering \\ Maulana Azad National Institute of Technology, Bhopal 462003, \\ Madhya Pradesh, India
}

\begin{abstract}
As the solar market is blooming and forecasted to continue this trend in the coming years. The efficiency and reliability of $P V$ based system has always been a contention among researchers. Therefore, multilevel inverters are gaining more assiduity as it has multitude of benefits. It offers high power capability along with low output harmonics. The main disadvantage of MLI is its complexity and requirement of large number of power devices and passive components. This paper presents a topology that achieves $37.5 \%$ reduction in number of passive components and power devices for five-level inverter. This topology is basically based on $\mathrm{H}$-bridge with bi-directional auxiliary switch. This paper includes a stand-alone PV system in which designing and simulation of Boost converter connected with multilevel inverter for ac load is presented. Perturb and observe MPPT algorithm has been implemented to extract maximum power. The premier objective is to obtain Voltage with less harmonic distortion economically. Multicarrier Sinusoidal PWM techniques have been implemented and analysed for modulation scheme. The Proposed system is simulated n MATLAB/Simulink platform.
\end{abstract}

\section{KEYWORDS}

MLI;P\&O MPPT algorithm;MC-SPWM; Boost converter.

\section{INTRODUCTION}

Increasing energy demands due to population growth and technology advancement, there is tremendous stress on our environment. Majority of electrical production are provided by fossil fuels like coal, natural gas and oil which contribute highly to the increasing $\mathrm{CO} 2$ production. Photovoltaic power generation is a technology that directly transforms unlimited, unpolluted and free solar energy into electric energy. Renewable energy resources include solar, wind, biomass, geothermal and tidal. These energy resources are not only clean, sustainable but also available in a large amount. However, there are some disadvantages with these sources like unreliability in supply, resource location and cost which prevents them from entering in mainstream energy sources. Solar Energy is becoming quite significant among sustainable energy system since it offers many advantages such as no fuel cost, no pollution, requirement of little maintenance and no noise. But solar PV system is accused of having relatively low conversion efficiency in order of $(12 \%-15 \%)$, high installation cost, and energy fluctuation and location dependency. The output power of PV array is dependent on temperature as well as solar radiation or insolation [1]. So with the variation in environmental temperature or insolation, PV power and maximum power point also varies. The non-linear characteristics of PV panel and underutilization (because of shading or low insolation) do affect the efficiency of a PV array. For tracking of a maximum operating point under a different environmental condition, we use controlled converter with maximum power point tracking algorithm. To make it use as standalone it must be converted from dc to ac with high efficiency and less total harmonic distortion. Therefore, multilevel inverter can be a good option for this.

DOI : 10.14810/ecij.2017.6201 
High power applications are in demand now-a-days. Many industrial applications require medium voltage and high power level [2]. Therefore, multilevel inverter can be a good alternative for applications like PV panel, wind and fuel cell. Conventionally, there are three topologies for MLI. But now-a-days researchers are working on reduced count topology because conventional topologies require a lot of power electronic switches and capacitors. The rating of these power electronics switches depend on the dc voltage source to which it is connected. Multilevel inverter has lots of advantages over conventional inverter. The voltage generated by MLI contains very less harmonics. Common mode voltage produced by MLI is very less which reduces stress on motor bearings. Input current of MLI contains less distortion. In addition to these MLI also works on low switching frequency which causes less switching loss and high efficiency.

\section{Proposed System}

This system consists of two stage stand-alone PV system in which voltage is stepped up by boost converter and then is converted to AC with the help of MLI. The P\&O MPPT algorithm is implemented to control the duty cycle of boost converter. The output voltage obtained by MLI consists of five levels with multicarrier sinusoidal pulse width modulation scheme. The block diagram of the stand-alone solar PV system is shown in figure 1.

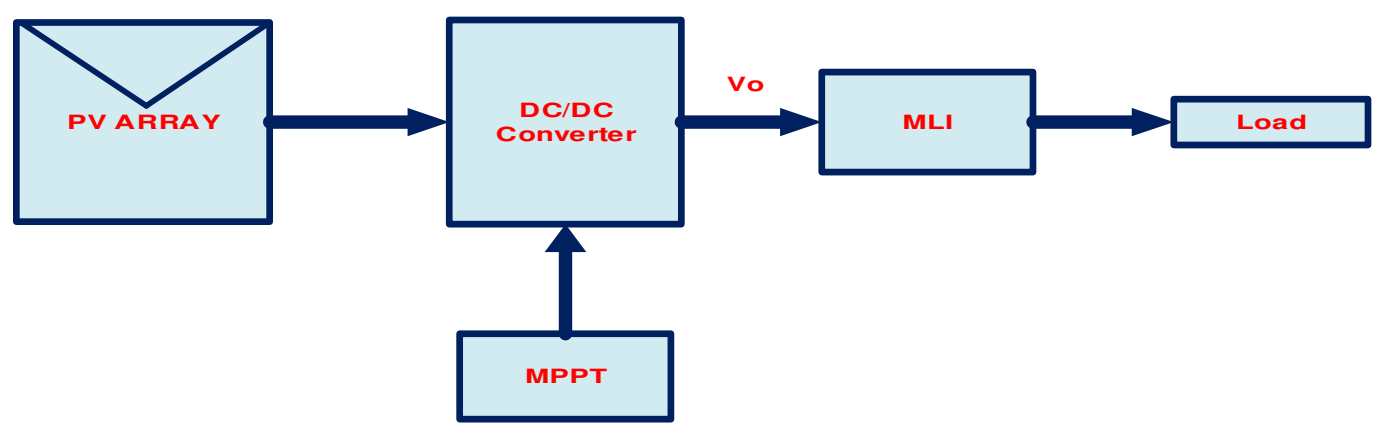

Figure1. Block diagram of system configuration

\section{Solar Pv ARray}

\subsection{OVERVIEW}

The proportional single diode model of a viable PV cell is shown in figure....It is also termed as five parameter model(n, Rsh, Rs, Io, Iph). RS is acquainted as with consider the voltage drops and inward misfortunes in because of stream of current. Rshtakes into record the spillage current to the ground when diode is backward one-sided.

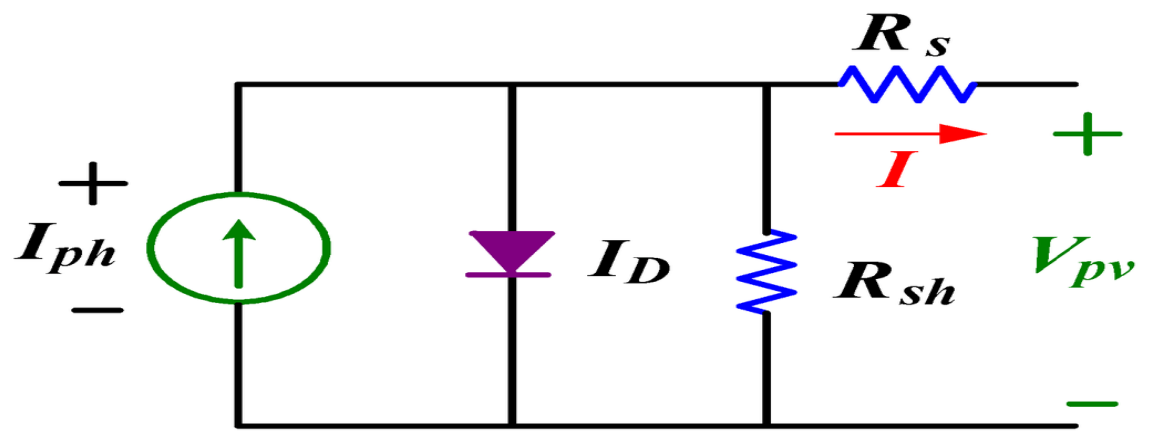

Figure2. Practical single diode model of PV cell 
Electrical \& Computer Engineering: An International Journal (ECIJ) Vol.6, No.1/2, June 2017

Where,

$\mathrm{n}$ is ideality factor of diode

$\mathrm{RS}$ is series resistance

Rshis parallel resistance

Iph is photon current which is directly proportional to solar insolation

ID is diode current

\subsection{SPECIFICATION OF SOLAR PV ARRaY}

UE Solar ZHM175 is the Solar Module that has been taken for Analysis and its data sheet is shown in Table 1 [3]-[4].

\begin{tabular}{|c|c|}
\hline Parameters & Values \\
\hline Maximum Power $(\mathrm{W})$ & 174.93 \\
\hline Cells per module $\left(\mathrm{N}_{\mathrm{cell}}\right)$ & 72 \\
\hline Open circuit voltage $\mathrm{V}_{\mathrm{oc}}(\mathrm{V})$ & 42.84 \\
\hline Short-circuit current $\mathrm{I}_{\mathrm{sc}}(\mathrm{A})$ & 5.39 \\
\hline Voltage at MPP, $\mathrm{V}_{\mathrm{mp}}(\mathrm{V})$ & 35.7 \\
\hline Current at MPP, $\mathrm{I}_{\mathrm{mp}}(\mathrm{A})$ & 4.9 \\
\hline Temperature coefficient of $\mathrm{V}_{\mathrm{oc}}\left(\% /{ }^{\circ} \mathrm{C}\right)$ & -0.3803 \\
\hline Temperature coefficient of $\mathrm{I}_{\mathrm{sc}}\left(\% /{ }^{\circ} \mathrm{C}\right)$ & 0.053154 \\
\hline
\end{tabular}

Table1.Parameters of solar module at insolation of $1000 \mathrm{~W} / \mathrm{m}^{\wedge} 2$ and temperature of $25^{\circ} \mathrm{C}$

The array is taken to get maximum power of $110 \mathrm{~kW}$ approximately and is connected as:

Number of Parallel Strings $=70$

Number of Series Connected modules per String $=9$

I-V and P-V characteristics of the PV array taken are shown in Figure 3-6

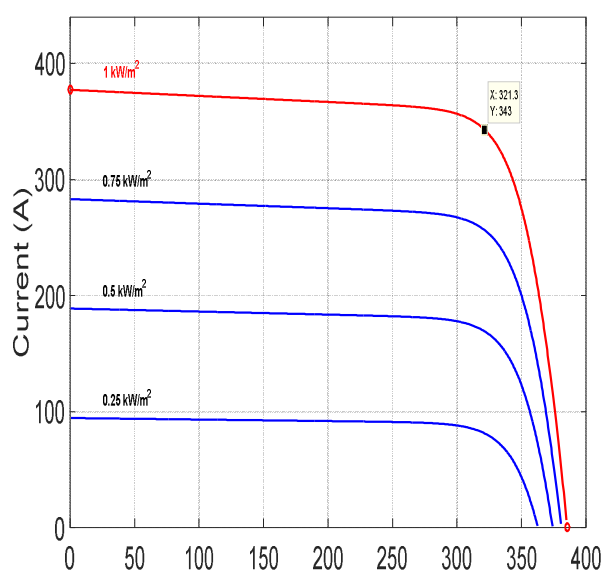

(a)

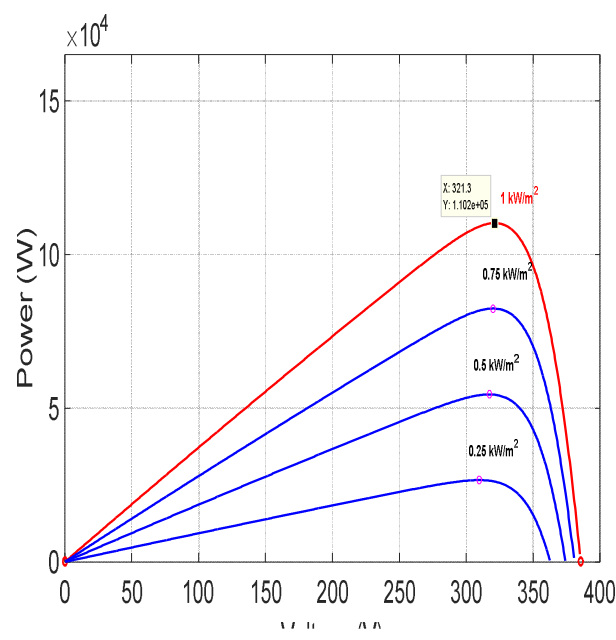

(b)

Figure3. Solar PV characteristic with different insolation and constant temperature.(a) Solar I-V characteristic; (b)P-V characteristic 


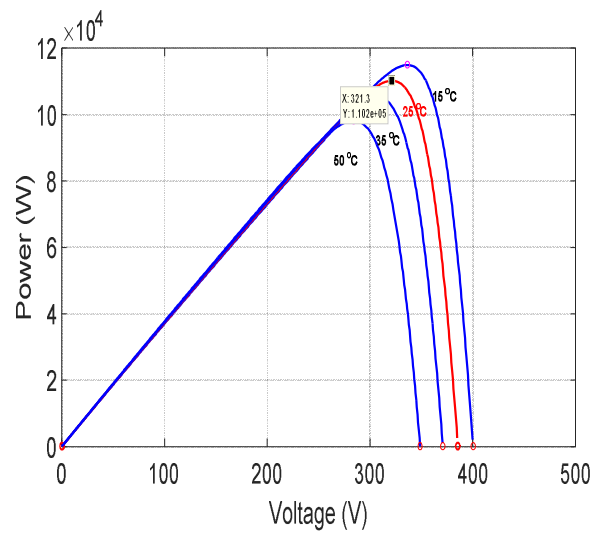

(A)

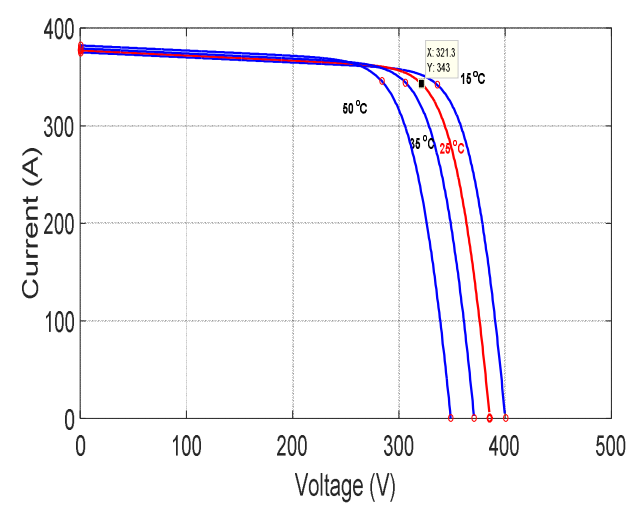

(B)

Figure4. Solar PV Characteristic With Different Temperature And Constant Insolation.(A) Solar I-V Characteristic; (B) Solar P-V Characteristic

\section{BOOST CONVERTER}

\subsection{OVERVIEW}

Boost converter is a class of switch-mode power supply which is used to step up DC voltage,having two semiconductor switches and two energy storing element as shown in figure7. When switch $\mathrm{S}$ is turned on, current flows through inductor and energy is stored. When Switch $\mathrm{S}$ is turned off, stored energy provides an induced voltage that is responsible for stepping up of voltage.

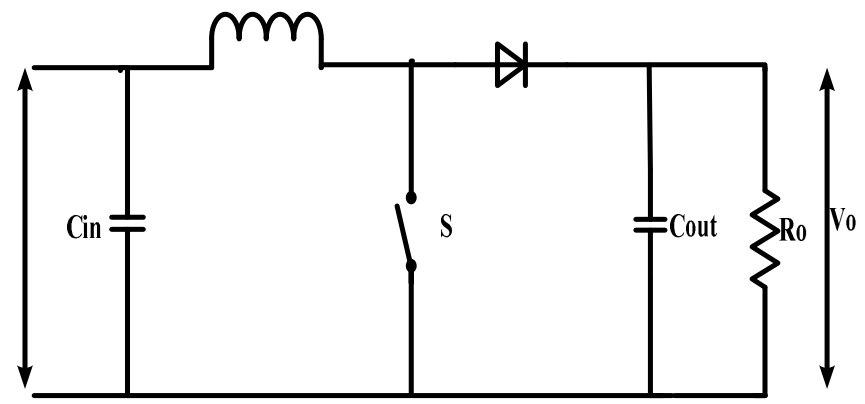

Figure5. Circuit diagram of boost converter

\subsection{Designing of Boost Converter}

While designing we have considered ideal boost converter. Selection of Inductor is done on the basis of estimated Inductor current ripple and can be calculated as [5]

$$
L=\frac{V_{1} \times\left(v_{v}-V_{i}\right)}{\Delta \varepsilon_{i} \times V_{0} \times V_{0}}
$$

Where, $\Delta \mathrm{I} \_(\mathrm{L})$ is the estimated inductor current ripple and can be calculated as

$$
\left.B I_{L}=0.1 \times I_{\text {U(m) }}\right)
$$


Above calculated value of inductor must be more than the critical value of inductor $\left(\mathrm{L}_{-} \mathrm{C}\right)$ otherwise boost converter will not be able to operate in current continuous mode. Critical Inductance can be calculated as

$$
L_{C}=\frac{D \times(1-D)^{2} \times R_{Q}}{2 \times f s}
$$

Selection of output capacitor is done on the basis of output voltage ripple and can be calculates as

$$
C=\frac{D}{\operatorname{Roxf} s \times\left(\Delta V_{0} / V_{0}\right)}
$$

Where, $\Delta \mathrm{Vo}_{\mathrm{o}}$ is the desired output voltage ripple and for voltage ripple of $1 \%$ of output voltage above equation can be rewritten as

$$
C=\frac{E}{\operatorname{sos} f \sin 0.01}
$$

D is the duty cycle corresponding to MPP and can be calculated as

$$
D=1-\sqrt{\frac{z_{M F F}}{z_{0}}}
$$

Where, $\mathrm{Z}_{\mathrm{MPP}}$ is the input impedance at Maximum Power Point and can be calculated as,

$$
Z_{M D P}=\frac{V_{M P E}}{T_{M F}}
$$

Load impedance must be chosen as

$$
Z_{0} \geq Z_{\text {MPF }}
$$

\begin{tabular}{|c|c|}
\hline Parameters & Values \\
\hline $\mathrm{V}_{\mathrm{HPF}}$ & 320 \\
\hline$I_{\mathrm{MPF}}$ & 343 \\
\hline $\mathrm{D}$ & 0.9 \\
\hline Frequency & $5 \mathrm{KHz}$ \\
\hline Vo & 3300 \\
\hline Inductor $(\mathrm{L})$ & $6 \mathrm{mH}$ \\
\hline Output Capacitor $\left(C_{\mathrm{os}}\right)$ & $1 \mathrm{mF}$ \\
\hline Input Capacitor $\left(C_{\text {nn }}\right)$ & $0.1 \mathrm{mF}$ \\
\hline
\end{tabular}

Table 2.Parameters of ideal boost converter 


\section{MPPT TEChNIQUe}

Several MPPT techniques together with their implementation are explained in the literature [6][10]. Researchers always face problem while choosing an MPPT technique for a particular application. Unfortunately, only a few techniques were available in this field including Curve fitting, Fractional Short Circuit Current, Fractional Open Circuit Volta Among all the MPPT methods, Perturb \& Observe (P\&O) and Incremental Conductance (IC) are most generally used because of simple implementation and less tracking time to track the maximum power point. Under suddenly changing weather conditions Incremental Conductance method can be a good choice. However, instead of more efficiency the complexity of the algorithm is very high compared to the former one and hence the cost of execution increases. So we have to extenuate with a trade-off between ramification and efficiency. Therefore, keeping in view the complexity and easy implementation $\mathrm{P} \& \mathrm{O}$ method is used here to track maximum power.

\subsection{Perturb \& Observe Algorithm}

Perturb and observe (P\&O) method is mostly used out of other method as it is simple and less expensive [11]. This algorithm is based on the sign of slope of $\mathrm{P}-\mathrm{V}$ curve of solar module. In this algorithm, voltage is perturbed and slope $(\mathrm{dP} / \mathrm{dV})$ is checked weather it is positive, negative or zero. If the slope is zero then that point is MPP and if slope is negative then voltage is perturbed in reverse direction else voltage perturbation is continued in same direction until we reach peak point. The algorithm for $\mathrm{P} \& \mathrm{O}$ is shown in Figure8.

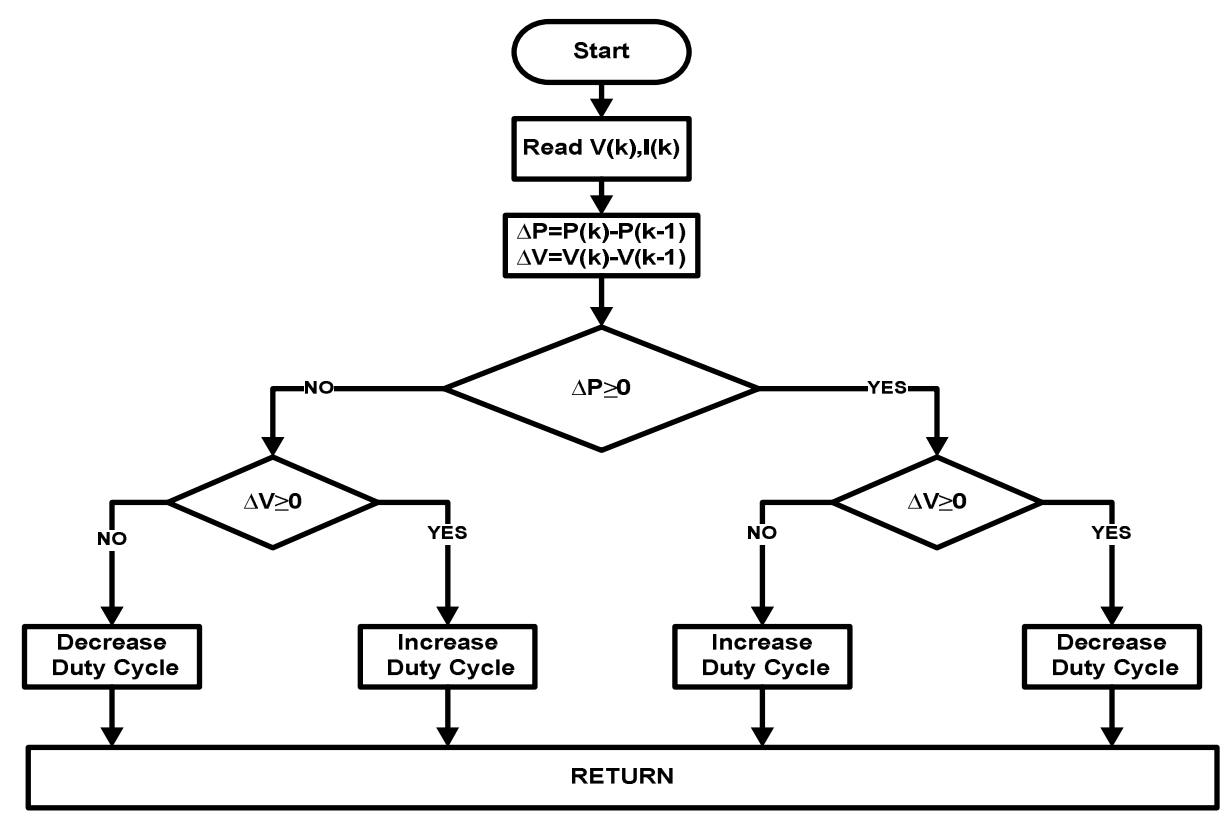

Figure6. Flow chart of P\&O MPPT algorithm

\section{MLi TOPOLOGY}

\subsection{Circuit Configuration}

The proposed MLI consists of a basic cell which produces five level of output voltage. The circuit diagram is shown in the figure9. 
Electrical \& Computer Engineering: An International Journal (ECIJ) Vol.6, No.1/2, June 2017

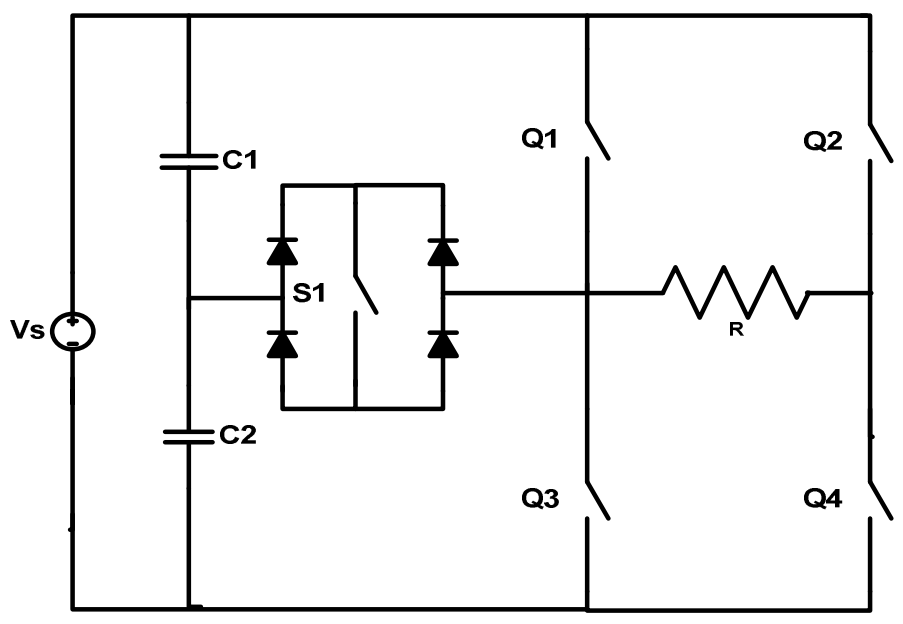

Figure7. Circuit diagram of diode clamped MLI

Proposed topology contains minimum number of switches for generating same number of output levels as compared to conventional MLI. This topology basically uses one voltage sources Vs (here voltage source represent stepped up DC-output voltage from PV arrays) and four power devices (Q1, Q2, Q3, Q4) and one auxiliary switch (S1) with four diodes.

\begin{tabular}{|c|c|c|c|c|}
\hline $\begin{array}{c}\text { Multilevel } \\
\text { Inverter } \\
\text { Type }\end{array}$ & $\begin{array}{c}\text { Diode } \\
\text { clamped }\end{array}$ & $\begin{array}{c}\text { Capacitor } \\
\text { Clamped }\end{array}$ & $\begin{array}{c}\mathrm{H} \\
\text { Bridge }\end{array}$ & $\begin{array}{c}\text { Asymmetric } \\
\text { Cascade }\end{array}$ \\
\hline $\begin{array}{c}\text { Main } \\
\text { Controlled } \\
\text { Switches }\end{array}$ & 8 & 8 & 4 & 8 \\
\hline $\begin{array}{c}\text { Auxiliary } \\
\text { Controlled } \\
\text { Switches }\end{array}$ & 0 & 0 & 1 & 0 \\
\hline Diodes & 20 & 8 & 8 & 8 \\
\hline Capacitors & 4 & 10 & 2 & 2 \\
\hline
\end{tabular}

Table 3.Comparison of Number of components between different five levels MLI

\subsection{WORKING}

The table 4 below gives the switching states of basic cell of proposed MLI. Here logic ' 1 ' is considered as 'ON' state and logic ' 0 ' is considered as 'OFF' state of the switches.

\begin{tabular}{|c|c|c|c|c|c|}
\hline S1 & $\boldsymbol{Q 1}$ & $\mathbf{Q 2}$ & $\mathbf{Q 3}$ & $\mathbf{Q 4}$ & Levels \\
\hline 0 & 1 & 0 & 0 & 1 & $\mathrm{Vs}$ \\
\hline 1 & 0 & 0 & 0 & 1 & $\mathrm{Vs} / 2$ \\
\hline
\end{tabular}


Electrical \& Computer Engineering: An International Journal (ECIJ) Vol.6, No.1/2, June 2017

\begin{tabular}{|c|c|c|c|c|c|}
\hline 0 & 0 & 0 & 1 & 1 & 0 \\
\hline 1 & 0 & 1 & 0 & 0 & $-\mathrm{Vs} / 2$ \\
\hline 0 & 0 & 1 & 1 & 0 & $-\mathrm{Vs}$ \\
\hline
\end{tabular}

Table 4.Switching Pattern of 5-level MLI

Reactive load has been considered as load in this case. At the Output terminal of boost converter, two capacitors are connected in parallel so that no voltage swing is produced in normal operation.

\section{Modulation SCHEME}

Appropriate Modulation Scheme is always required to generate and control high quality Output of MLI. Various techniques for modulation have been discussed in literature like Multi-carrier Pulse width Modulation and space Vector modulation [13].Here, due to simplicity and easy implementation MCPWM scheme has been discussed.

To generate five levels output four carrier signals are required. Different way to generate multicarrier signals based on level shift has been shown in figures 6 .

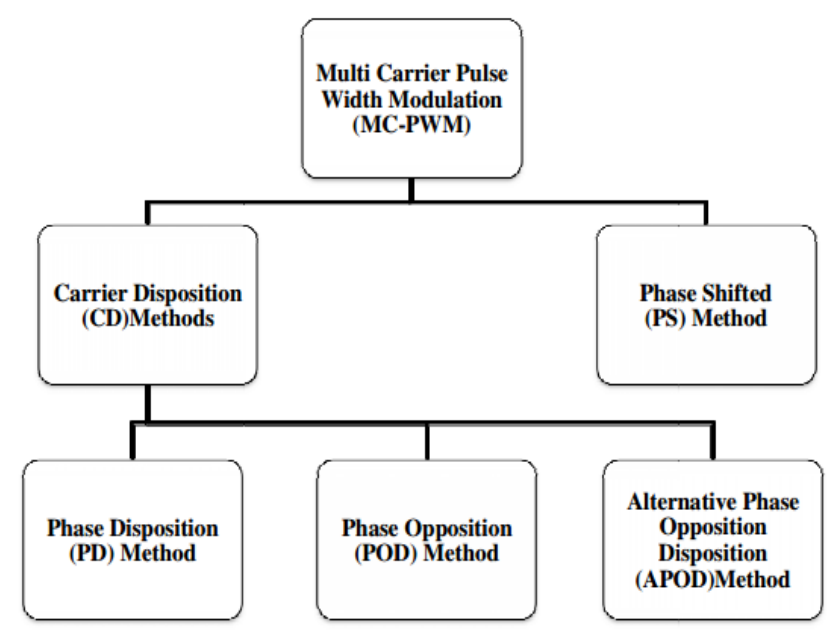

Figure8.Classification of PWM modulation schemes

\subsection{Phase Disposition (Pd-PwM)}

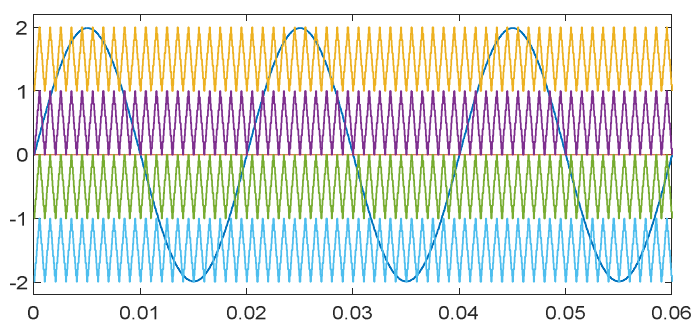

Figure9. PD scheme waveform

In this scheme all the carrier signals are in phase and level Shifted. The zero reference is placed at the middle of the carrier set. 


\subsection{Phase Opposition Disposition (PoD-PWM)}

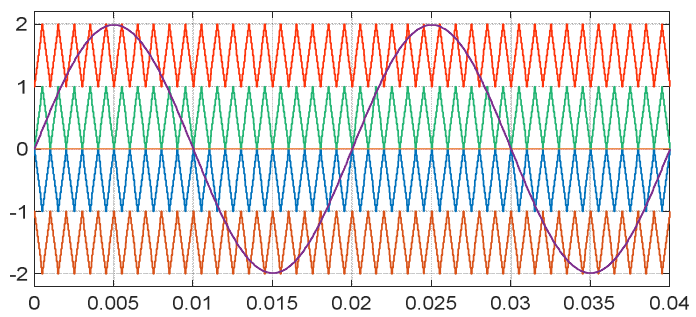

Figure10. POD Scheme waveform

In this scheme all the carrier signal above zero reference are in same phase and all the carrier signals below zero reference are shifted by 180 degree.

\subsection{Alternate Phase OpPosition Disposition (APOD-PWM)}

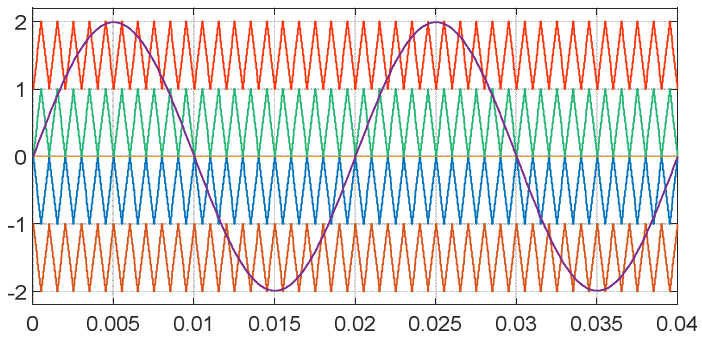

Figure11.APOD Scheme waveform

In this technique all the carrier signals are alternately disposed in Phase by 180 degree. Reference signal is placed in the middle of carrier.

The comparison of different modulation schemes are shown in Table4.Here ma and $\mathrm{mf}$ are amplitude and frequency modulation index respectively.

$$
\begin{gathered}
m_{a}=\frac{A_{m}}{(m-1) A_{\mathbb{I}}} \\
m_{t}=\frac{f c}{f_{m}}
\end{gathered}
$$

Where, Am and Ac is amplitude of modulating and carrier signal respectively. fmand fc are frequency of modulating and carrier signal. Number of level is represented as $\mathrm{m}$.

\begin{tabular}{|c|c|c|c|}
\hline & $\begin{array}{c}\boldsymbol{P D} \\
m_{a}=.85\end{array}$ & $\begin{array}{c}\text { POD } \\
m_{a}=.85\end{array}$ & $\begin{array}{c}\text { APOD } \\
m_{n}=.85\end{array}$ \\
$m_{f}=40$ & $m_{f}=40$ & $m_{f}=40$ \\
\hline $\begin{array}{c}\text { THD \% in } \\
\text { voltage } \\
\text { waveform }\end{array}$ & 23.37 & 22.23 & 22.67 \\
\hline
\end{tabular}

Table4. Comparison of THD \% with different modulation schemes 
Electrical \& Computer Engineering: An International Journal (ECIJ) Vol.6, No.1/2, June 2017

\section{Simulation Results}

The following results are obtained with constant insolation of $1000 \mathrm{~W} / \mathrm{m}^{\wedge} 2$ and Temperature of $25^{\circ} \mathrm{C}$. The switching frequency of boost converter and inverter is taken $5 \mathrm{KHz}$ and $2 \mathrm{KHz}$ respectively. Resistance of $100 \mathrm{ohm}$ is taken as load.

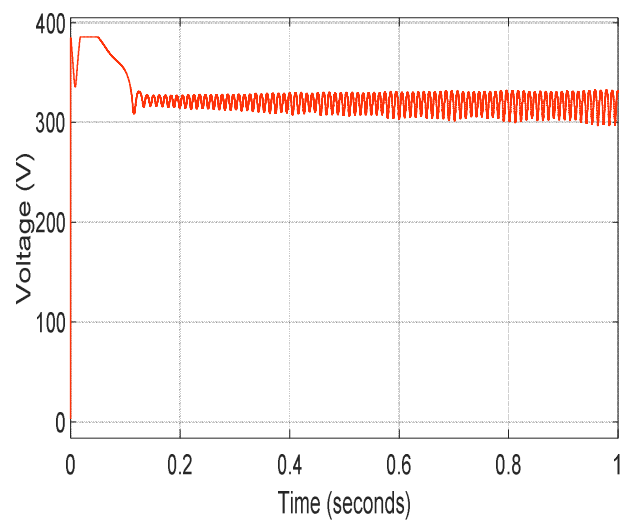

Figure12.PV voltage of solar panel

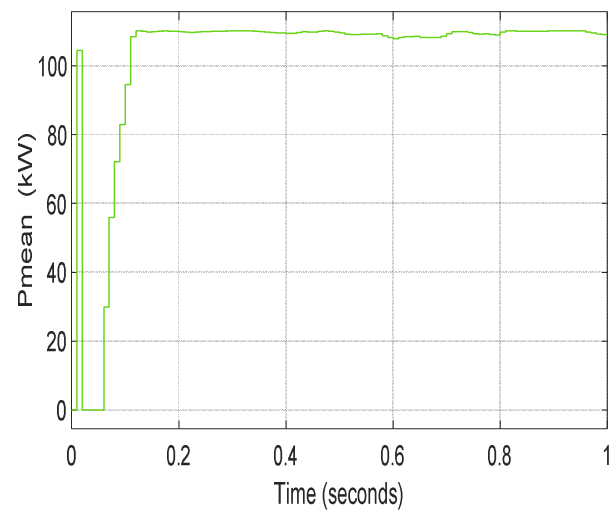

Figure14.PV power of solar panel

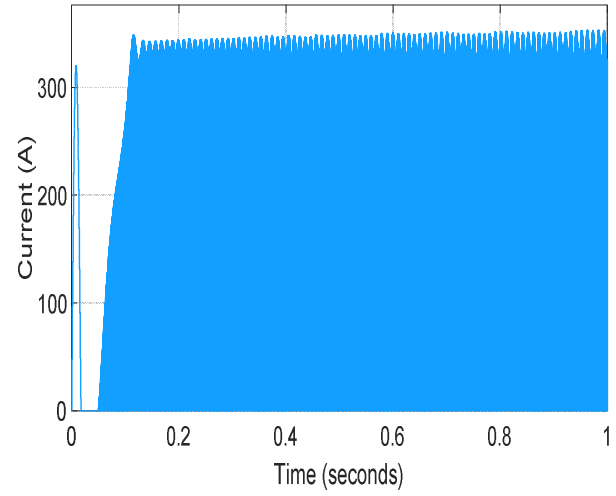

Figure16.Output Current of boost converter

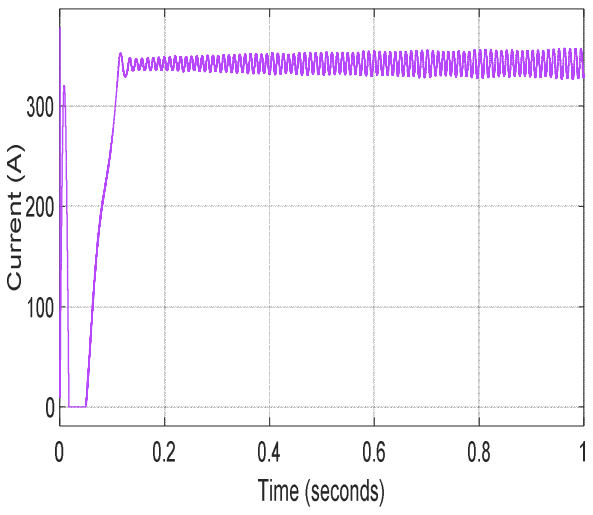

Figure13.PV Current of solar panel

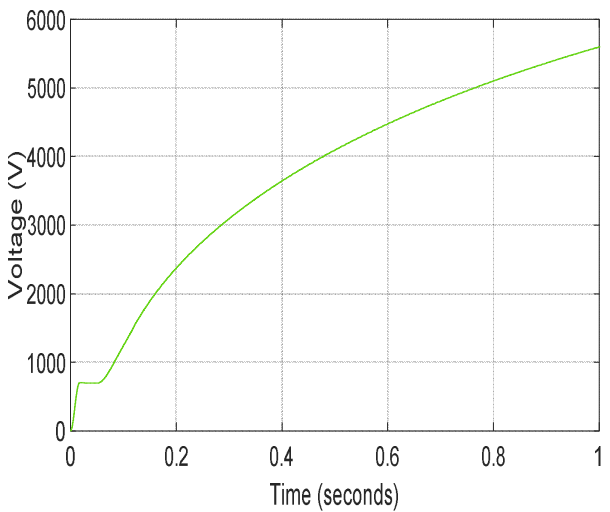

Figure15.Output voltage of boost converter

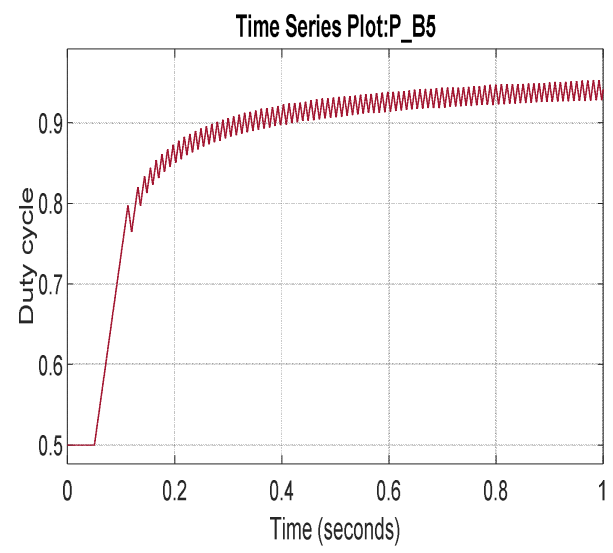

Figure17. Duty cycle of boost converter 


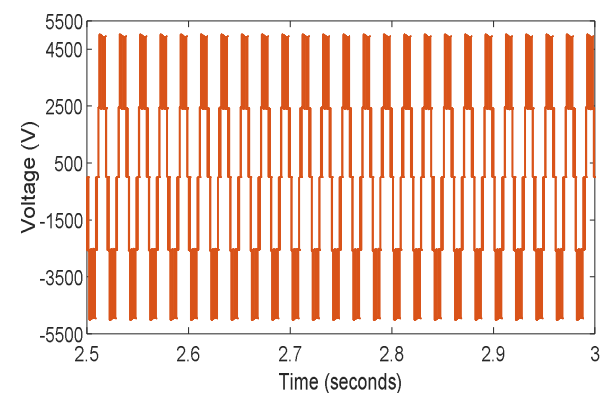

Figure18. Output voltage of MLI

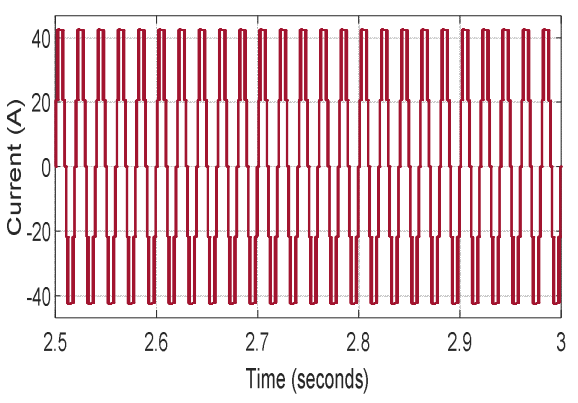

Figure20. Output Current of MLI

\section{CONCLUSION}

The paper presents a comprehensive analysis and simulation in MATLAB Simulink. The P-V and V-I curve is plotted for different temperature and insolation.The P\&O MPPT algorithm is also implemented to extract maximum power with direct duty ratio control. Different curves of PV voltage, PV current, Boost converter outputs are obtained. Output voltage with five levels is obtained as expected with the bi-directional switch. The THD in output voltage of system is $22.23 \%$ without any filter. A significant reduction in number of switches is obtained. The aforementioned topology can also be used for asymmetric source configuration. Number of levels can also be increased by connecting this topology in cascade manner, as the number of levels increase it ameliorate the power quality and can moderate the need of filter.

\section{ACKNOWLEDGEMENT}

The author would like to thank everyone, just everyone!

\section{REFERENCES}

[1] Weidong Xiao; Edwin, F.F.; Spagnuolo, G.; Jatskevich, .I.,"Eflicient Approaches for Modeling and Simulating PhotovoltaicPower Systems," Photovoltaics, IEEE Journal of , vol.3, no.1,pp.500,508, Jan. 2013.

[2] Franquelo, L.G.; Rodriguez, .I.; Leon, .1.1.; Kouro, S.; Portillo, R.; Prats, M.AM.; , "The age of multilevel converters arrives," Industrial Electronics Magazine, IEEE, vol.2, no.2, pp.28-39, June 2008.

.[3] Dash, S.K.; Raj, R.A.; Nema, S.; Nema, R.K., "Development of photovoltaic (PV) cell/module/array and non-uniform irradiance effect based on two-diode model by using PSPICE simulator,"

[4] Nema R K, SavitaNema, GayatriAgnihotri. Computer simulation based study of photovoltaic cells/modules and their experimental verification. International Journal of Recent Trends in Engineering 2009;1.3:156-151.

[5] D.Verma,S.Nema,A.M.Shandilya," A Di®erent Approach to Design Non-Isolated DC-DC Converters for Maximum Power Point Tracking in Solar Photovoltaic Systems," Journal of Circuits, Systems, and Computers Vol. 25, No. 8 (2016) 1630004 (22 pages).

[6] BidyadharSubudhi, Senior Member, IEEE, and RaseswariPradhan, "A Comparative Study on Maximum Power PointTracking Techniques for Photovoltaic Power Systems," IEEE Transactions on Sustainable Energy, Vol. 4, No. 1, January 2013

[7] D. Verma, S. Nema, A. M. Shandilya and S. K. Dash, Comprehensive analysis of maximumpower point tracking techniques in solar photovoltaic systems under uniform insolation and partial shaded condition, J. Renew. Sust.Energy 7 (2015) 042701.

[8] D. Verma, S. Nema, A. M. Shandilya and S. K. Dash, Maximum power point tracking(MPPT) techniques: Recapitulation in solar photovoltaic systems, Renew. Sust.EnergyRev. 54 (2016) 10181034. 
[9] S. K. Dash, S. Nema, R. K. Nema and D. Verma. A comprehensive assessment of maximum power point tracking techniques under uniform and non-uniform irradiance and its impact on photovoltaic systems: A review, J. Renew. Sust.Energy 7(6) (2015) 063113.

[10] S. K. Dash, D. Verma, S. Nema and R. K. Nema, Comparative analysis of maximum power point (MPP) tracking techniques for solar PV application using MATLAB Simulink, Recent Advances and Innovations in Engineering (ICRAIE), Jaipur, India, 09-11 May 2014, pp. 1-7.

[11] F. Liu, Y. Kang, Y. Zhang, and S. Duan, "Comparison of p\&o and hill climbing MPPT methods for grid-connected PV generator," inProc.3rd IEEE Conf. Industrial Electron.Applicat., Singapore, Jun. 3-5,2008.

[12] A. Nabae, I. Takahashi, and H. Akagi, “A new neutral-point clamped PWM inverter," IEEE Trans. Industry Applications, vol. IA-17, pp. 518-523, September/October 1981.

[13] Agarwal,R;Tandekar,J.A;Jain,S; "Multi-carrier pulse width modulation schemes for multilevel converters," Electrical, Electronics and Computer Science (SCEECS),IEEE Students' Conference on, DOI: 10.1109/SCEECS.2016.7509285,2016

[14] Babaei, E.;, "A Cascade Multilevel Converter Topology With Reduced Number of Switches," Power Electronics, IEEE Transactions on, vo1.23,no.6, pp.2657-2664, Nov. 2008.

[15] Hinago, Y.; Koizumi, H.; "A Single-Phase Multilevel Inverter Using Switched Series Parallel DC Voltage Sources," Industrial Electronics,IEEE Transactions on, vol.57, no.8, pp.2643-2650, Aug. 2010.

[16] Gupta, K.K.; Jain, S., "Comprehensive review of a recently proposed multilevel inverter," Power Electronics, 1ET, vol. 7, no.3, pp.467,479,March 2014.

[17] Kangariu, M.F.; Babaei, E.; Sabahi, M., "Cascaded cross-switched multilevel inverter in symmetric and asymmetric conditions," Power Electronics, lET, vol.6, no.6, pp. 1 041,1050, July 2013.

[18] Mokhberdoran, A; Ajami, A, "Symmetric and Asymmetric Design and Implementation of New Cascaded Multilevel Inverter Topology," Power Electronics, IEEE Transactions on, vol.29, no.12, pp.6712,6724, Dec 2014.

[19] Kangarlu, M.F.; Babaei, E.;, "A Generalized Cascaded Multilevel Inverter Using Series Connection of Submultilevel Inverters," Power Electronics, IEEE Transactions on, vol.28, no.2, pp.625-636, Feb. 2013.

\section{AUTHORS}

Amarnath was born in chhapra Town, Bihar State, India in 1992. He received the B.Tech degree in Electrical engineering from the Uttar Pradesh Technical University, Lucknow in 2014. Currently, he is pursuing M.Tech in Electrical Drives from Maulana Azad National Institute of Technology, Bhopal. His research interests include multilevel inverters, alternative energy sources, energy conversion, power quality, active filter harmonic analysis and control.

Dr. Deepak Verma received BE degree in Electrical Engineering from RGTU, Bhopal (2008), M.Tech degree (2010) from MANIT and Ph.D degree (2016) from MANIT Bhopal, India. His research interest includes Solar Photovoltaic, MPTT, Grid interconnection of renewable energy and residential photovoltaic energy storage system.

Dr. Deepak Verma received BE degree in Electrical Engineering from RGTU, Bhopal (2008), M.Tech degree (2010) from MANIT and Ph.D degree (2016) from MANIT Bhopal, India. His research interest includes Solar Photovoltaic, MPTT, Grid interconnection of renewable energy and residential photovoltaic energy storage system.
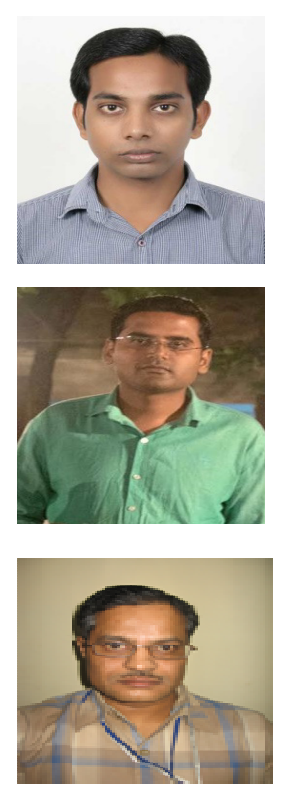